\title{
INTERNATIONAL ORGANIZATIONS FROM THE SOVIET POINT OF VIEW
}

\author{
KaZIMIERZ GrZYBowsKI*
}

\section{I}

\section{The Historical Background}

Soviet current policies in the United Nations Organization and in relatiuns with the free world at large have their roots in the early days of the revolutionary régime, when the October Revolution gave power to the Bolshevik Party. At that time Russia, one of the great European powers, was on the brink of military disaster due to her involvement in war and her alignment with the Entente in conflict with the Central Powers. The defeat of the imperial army sowed the seeds of the revolution. At the same time, the new régime was painfully aware that in order to survive and to save the country from foreign conquest and political disintegration it must drastically change the situation. It was imperative that Russia be extricated from the war.

The idea of political and military disengagement was by no means the monopoly of the Bolshevik Party. It had its partisans in the imperial government, in certain political circles in Russia, and even among the members of the imperial family. The strength of the Bolsheviks lay in the fact that only they had a political theory and a philosophy of neutrality in that period of history and in that particular situation. Lenin's views, formulated in his major work, State and Revolution, served to make virtue of Russia's inability to fulfill the terms of the Alliance, and furnished a plan for action. According to Lenin the war was an imperialist war, fought not for the ideals of liberation, but for control of markets and world supply of raw materials. The real aim of the warring parties was to increase their dominions by the enslavement of the weaker nations. The decree on Peace, which was one of the first acts of the new régime, declared that: "To continue this war for the sole purpose of determining how to shape out control of the subjugated nations by the rich and powerful countries was a major crime against humanity."1

In order to stop the war, the Bolshevile régime proposed an immediate conclusion of peace, and sued for peace itself.

The decree repudiated the alliance with Western powers. In order to justify it, the Bolsheviks published secret treaties and agreements between Russia and other members of the Entente regarding post-war territorial settlements which indeed anticipated vast acquisitions for Russia, France, and Britain. Furthermore, the new

* M.L.L. I931, Dr. iur. 1932, University of Lwow, Poland; S.J.D. 1934, Harvard University. Lecturer in International and Comparative Law, University of Lwow, 1936-39. Senior Research Associatc, Rule of Law Research Center, Duke University. Author, Soviet Legal Institutions: Doctrines and Socinl Functions (1962); The Socialist Commonwealth of Nations (1964).

${ }^{2}$ S.U. RSFSR (Soviet Laws), I9r7-18, no. I. 
régime looked with suspicion at various plans of the Western Powers to help Russia in her war effort. According to Potemkin's History of Diplomacy, which was to establish the official record of those times for the instruction of posterity, in the Fall of IgI7 Britain, the United States, and France had reached an agreement to cooperate in "assistance" to Russia. The United States assumed responsibility for the reorganization of Russian railways, and Britain, for the development and equipment of the sea transport, while France undertook to give assistance to the army. However, the terms of the agreement were changed in a manner which in Russian eyes was proof of the far from friendly intentions of the Western Allies. Assistance to the Murmansk railway was assigned to Britain, while Western and South Western railways were to come under the French control. The Russians feared that the new agreement was not only a case of gross intervention in the internal affairs of Russia, but a first step towards her partition into foreign spheres of influence. ${ }^{2}$ Thus, as the new masters saw it, Russia's war sacrifices earned her nothing but defeat and humiliation, and held a prospect of enslavement at the hands of her imperialistic friends. To serve the nation and the interests of humanity the Bolshevik régime felt entitled to seek a separate peace with the Central Powers.

The decree on Peace, which declared void all secret treaties which were to benefit Russian landowners and the capitalist class, the ruling class in the Empire; was followed by another measure, this time aiming at the economic disengagement of Russia. The decree of People's Commissars of January 28, I9I8 annulled "finally and without exception" all foreign loans to the previous régime as contrary to the new political reality. ${ }^{3}$

Stated in those terms, the policy disengagement remained for a long time the guiding line of Soviet foreign policy. Its main idea was that the socialist state is, by its very nature, free from those entanglements which result from the struggle and ambitions of the imperialist powers: Soviet policy is such that it cannot be affected by the conflicts and internal contradictions of the world economic and political order.

The fullest exposé of the position of the socialist Russia in world affairs was made by the Russian delegation to the Genoa Conference (April-May I922), which sought to re-establish the economic and political unity of Europe. One of the key problems vis-à-vis Russia was the reconstruction and revival of her industrial and economic assets, to make her again a partner in foreign trade. This was impossible without foreign capital, and the members of the Conference sought to convince the new Russian régime that its repudiation of foreign loans and nationalization of foreign enterprises were obstacles to effective economic cooperation. Before new capital was made available, the Russian government had to mend its ways and make some concession to foreign interests. However, this plea fell on deaf ears. The Russian delegation refused to discuss the matter in terms of practical steps and came out

22 Istoria Diplomatil (History of Diplomacy) 302 (1945).

${ }^{3}$ S. U. RSFSR (Soviet Laws), x917-18, nos. 353, 386 . 
with a broad statement of principle, which justified its past policy, and asserted that the Russian régime was entitled to discuss terms of economic cooperation on the basis of new agreements and commitments. In its memorandum of May IX, I922, the Russian delegation stated that:

... revolutions, which are a violent rupture with the past, carry with them new juridical relations in the foreign and domestic affairs of states. Governments and systems that spring from the revolution are not bound to respect the obligations of fallen governments. ${ }^{4}$

However, principle or no principle, as time went on, the Russian government was forced to modify somewhat its position as regards the binding force of the acts of the previous Russian government. In an exchange of notes with the British government and later on various different occasions, the Soviet government either confirmed the validity of a number of earlier agreements, or withdrew its basic opposition to being bound by the tsarist treaties. Either by governmental proclamation, by reference in new laws, or official accessions, and even indirectly by publishing the texts of treaties in force, a number of international agreements pre-dating the revolution was recognized as remaining in force. ${ }^{5}$ In particular, the Soviet régime found it useful to continue its cooperation with other countries within the framework of various technical and specialized organizations.

In the course of the twenties, the Soviet Union slowly built up its membership and participation in already established international organizations, including various technical arrangements. The Soviet Union became a party to the International Metric Union, International Telegraph Union, International Convention Concerning Protection of Underwater Telegraph Cables, Convention Concerning Establishment of an International Union for the Publication of Customs Tariffs, Convention Concerning Establishment of a Permanent International Agricultural Institute, International Office for Public Health, International Agreement for the Creation of an International Office Dealing with Contagious Diseases of Animals, Universal Postal Convention, Convention for the Creation in Paris of an International Office of Chemistry, Convention for the Unification of Certain Rules of International Air Traffic, and so on.

However, while the Soviet Union sought to cooperate in technical organizations, it refused to be involved in political schemes for the preservation of peace. It remained a partisan of the doctrine of political disengagement, which, as its leaders believed, saved the revolution. Not invited to become a member of the League of Nations, the Soviet government maintained an attitude of criticism and disapproval of the régime for the preservation of peace established under its auspices.

A subtle change in the Soviet line occurred in the late twenties, when the Soviet Union decided to join the General Treaty for the Renunciation of War as an Instrument of National Policy (Kellogg-Briand Pact-Treaty of Paris) of August 27, 1928.

‘ CMD. No. 1667 , at 42-43 (1922).

${ }^{5}$ Cf. note 7 infra. 
This was a first demonstration of Soviet active interest in some forms of collective security. The I928 Treaty was followed by three regional agreements connected with its provisions. On February 9, Ig29 the Soviet Union signed a Protocol concerning the entry into force of the Paris Treaty for the Renunciation of War (Litvinov Protocol) with Danzig, Poland, Estonia, Latvia, Lithuania, Persia, and Romania. On July 3, r933, the Soviet Union concluded a convention on the definition of aggression with Afghanistan, Estonia, Finland, Latvia, Persia, Poland, Romania, and Turkey, and the next day a similar convention with Czechoslovakia, Turkey, and Yugoslavia.

The new line of policy which slowly took shape in the late twenties and early thirties was largely due to the growing change in the political climate in Europe. While initially the Soviet Union could maintain a posture of neutrality in a world which faced no real chance of major conflagration, the emergence of the dictatorial régimes in Italy and Germany, and the growing might of the Japanese Empire and its conquests on the Asian mainland made the Soviet Union vitally interested in the preservation of the status quo and in preventing wars. Soviet leaders saw themselves slowly becoming the main targets of political propaganda campaigns and even attacked by military force in Soviet territorial possessions. In those circumstances the Soviet Union was forced to abandon its policy of isolation, and to seek contact and cooperation with the forces of stability and political status quo.

In 1933 , in a move to strengthen its position, Soviet intransigence as regards noncompensation for the nationalization of foreign property was abandoned. The actual concession was not important and involved no financial outlay on the part of the Soviet Union. In November 15, I933, the Soviet government concluded a Gentlemen's Agreement (Litvinov Assignment), with the United States concerning the settlement of the pre-Soviet Russian government debts to the United States. The following day the Soviet Union and the United States exchanged notes establishing diplomatic relations between the two countires. In 1934 the Soviet Union joined the League of Nations and the International Labor Organization (ILO).

Soviet policy of active participation in various collective security schemes was closely associated with the person of Maxim Litvinov, who after long years in the Soviet foreign service finally reached the position of the foreign commissar of the Soviet Union. There seems to be no doubt that Litvinov himself was earnestly convinced that Soviet security could not be assured except by adhering to the policy of collective security. However, his position in the government and in the Party was not strong enough to commit the Soviet Union to this policy. Soviet entry into the League was understood as an act of political demonstration and a new line in the Soviet political tactics rather than a genuine change of heart. There was little evidence that the Soviet Union rendered more than lip service to the aims and goals of the League of Nations. At any rate its contribution to the prestige and power of the League could not but only delay (if at all) the process of disillusionment with 
the effectiveness of the great organization, which barely a dozen years earlier was a source of hope for the world.

Similarly, Soviet representatives in the ILO have done little to promote the work and the aims of the Organization. In spite of the fact that Soviet delegates participated in five of its annual sessions (19-23), the Soviet government did not accede at that time to a single of its conventions or agreements seeking to establish international standards of employment and improve world labor conditions. Some of the conventions prepared at that time and approved, also by the Soviet delegation at the ILO meetings, were ratified by the Soviet Union only after the death of Stalin (1953). A Soviet manual describing Soviet participation in the work of the ILO suggested that Soviet delegates to the ILO used its sessions mainly to "expose willful lies concerning the position of Soviet labor and to inform the public of the great achievement of the socialist country."

As time went on, Soviet leadership became convinced that the policy of collective security was not a realistic policy, committing an error of judgment similar to that made by the governments of the other great powers of Europe. (Munich Agreement of 1938.) In March I939 Litvinov was replaced by Molotov, who until that time was the chairman of the Council of the People's Commissars, and Stalin assumed direct responsibility for the government of Russia, taking in turn Molotov's position. The new leadership came to terms with Germany and became a party to the Ribbentrop-Molotov Pact (August 24, 1939). More than twenty years after Soviet leaders had successfully experimented with the disengagement maneuver the Soviet government again resorted to the same policy.

\section{II}

\section{Soviet Participation in Universal International Organizations Since 1945}

In the perspective of historical experience, the question which must be asked today is, what is the nature of the Soviet government participation in international programs involving technical cooperation with other countries, or in organizations seeking to guarantee peace and collective security in the world?

In the post-World War II period, the Soviet Union built up its membership in international organizations to the imposing number of some two hundred forty associations concerned with activities of interest to more than one country. In all probability in the entire world there is no other country with a government involved in so many international activities. This high figure is primarily due to the unique approach of the socialist countries to international relations. In more traditional societies a good deal of international contact is left to private individuals and private associations. In the Soviet Union and other socialist states, activities of business and professional association, of scholars, artists, labor leaders, humanitarians,

aezhounarodnoe Ekonomicheskie Organizatsi (International Economic Oroanizations) 138 (rg62 ed.). 
if they extend beyond national boundaries, are a matter of foreign relations and a government monopoly. Thus the Soviet government in its official capacity is represented in all type of international associations which, so far as other countries are concerned, are not inter-governmental organizations. These include those established for the promotion and advancement of international research and exchange of information in the field of natural sciences, of humanities (history, Slavic studies), social studies (International Penal Law Association), cancer, rheumatism, shipbuilding and construction of roads and bridges, which although international in scope are "private" in nature. In addition the Soviet Union takes part in various organizations active in the field of trade and economic cooperation, international trade union activities, the International Red Cross Organization, and so on. Not all international organizations of which the Soviet Union is a member are international in the traditional sense. Yet, even with those corrections, Soviet membership in international organizations is quite impressive.

Soviet membership in inter-governmental organizations falls in three categories:

By far the largest is that group of international associations which were set up to deal with concrete, mostly technical problems of international cooperation. They include railway transport, electric power and its transit, communications including wireless, protection of natural resources (North Pacific Fur Seal Commission, International Whaling Commission, North Pacific Fisheries Commission, and so on). However, the Soviet Union remains uncommitted to international programs for the protection of copyright and of industrial property, as such rights are differently conceived and protected by the socialist states for reasons determined by national policy rather than out of respect for individual initiative and personal creation.

The second category of Soviet international involvement represents those forms of collective activity which, broadly speaking, form the United Nations system of international organizations.

In addition to the U.N., of which the Soviet Union is one of the original members, the Soviet Union is a member of the International Labor Organization (since I954 also Ukraine and Byelorussia have joined ILO); the Economic and Social Council, Trusteeship Council, Bureau of Technical Assistance of the United Nations (the Soviet Union contributes financially to that organization since I953); the Universal Postal Union, World Meteorological Organization, World Health Organization, UNESCO (since I954), and the International Atomic Energy Agency.

The Soviet Union is not a member of the following technical organizations which are a part of the U.N. system: International Bank for Reconstruction and Development; International Monetary Fund; International Finance Corporation; Food and Agricultural Organization; International Civil Aviation Organization; Inter-Governmental Maritime Consultative Organization.

Soviet lack of interest in these organizations, especially those that are designed to render financial and economic assistance to underdeveloped countries, seems 
to be indicative of a fundamental opposition to international control of this type of activity, and may be dictated by a number of reasons. It cannot be excluded that the Soviet Union, a country with one of the largest national budgets in the world is unable to contribute to those activities in proportion to its position and influence in world affairs, a matter of prestige which is an important consideration in Soviet international policies. In addition the Soviet Union has its own program of economic assistance to other countries, which it administers according to policies dictated by its national interest, and which obviously is in conflict with the policy of international bodies. The same reason may inspire Soviet non-participation in the Inter-Governmental Maritime Consultative Organization, which is to bring agreement and cooperation in this aspect of international economic activity, and where the Soviet Union has aspirations exceeding its present possibilities.

Soviet participation in various United Nations activities underwent a subtle change since the death of Stalin and subsequent removal of Molotov from the control of foreign policies of the Soviet Union. Soviet foreign policy became more active and more inclined to compromise (e.g., Austria and Laos). The Soviet Union joined UNESCO; and its participation in the International Labor Organization ceased to be a purely nominal affair. Since I954 the Soviet government began to take active part in ILO's efforts to establish uniform labor conditions in the world by ratifying some of the numerous international conventions prepared and voted at ILO sessions. ${ }^{7}$

It must be said at once that by no means the Soviet Union became more amenable to identify its policies fully with those of the United Nations. The change, however, signified a more rational attitude to the work of the U.N., and to cooperation with its programs, when this was in the Soviet Union's interest.

${ }^{7}$ Convention concerning decrease of work hours to forty hours per week (ILO no. 47) of June 22, I935, ratified by the Soviet Union on June 4,1956 .

Convention concerning annual holidays with pay (ILO no. 52) of June 24, 1936, ratified by the Soviet Union on July 6, 1956.

Convention fixing the minimum age for the admission of children to employment at sea (ILO no. 58) of October 24, 1936, ratified by the Soviet government on July 6, 1956 .

Convention fixing the minimum age for admission of children to industrial employment (ILO no. 57) of June 22, 1937, ratified by the Soviet Union on July 6, 1956 .

Convention concerning the age for admission of children to non-industrial cmployment (ILO no. 60), ratified by the Soviet Union on July 6 , 1956.

Convention concerning medical examination for fitness for employment in industry of children and young persons (ILO no. 77) of October 9, 1946, ratified by the Soviet government on July 6, 1956.

Convention concerning the restriction of night work of children and young persons in non-industrial occupations (ILO no. 78) of October 9, 1936, ratified by the Soviet Union on July 6, 1956.

Convention concerning freedom of association and protection of the right to organize (ILO no. 87) of July 9,1948 , ratified by the Soviet Union on July 6 , 1956.

Convention concerning the night work of young persons emplojed in industry (ILO no. 90) of July Io, I949, ratified by the Soviet Union on July $6,1956$.

Convention concerning the application of the principles concerning the right to organize and to bargain collectively (ILO no. 98) of July 10, 1949, ratified on July $6,1956$.

Convention concerning equal remuneration for men and women workers for work of equal value (ILO no. IO0) of June 29, 1951, ratified by the Soviet government on April 4, 1956.

Convention concerning maternity protection (ILO no. ro3) of June 28 , r952, ratified by the Soviet government on July 6 , 1956 . 
Soviet attitude towards some of the work done at the U.N. seems to indicate that a common policy uniting capitalist and socialist countries in certain fields of international activity is affected by the ideological diffculties stemming from different conceptions as to the historical sense of our times.

\section{III}

\section{Regional Organizations Within the Soviet Bloc}

In contrast, in relations between the socialist countries, the Soviet Union has demonstrated vigor and initiative in developing programs to realize a concrete vision of a future world order, of which the present political and economic alignment of the socialist nations is only a beginning.

To achieve this purpose the Soviet Union and the associated socialist countries of Europe and Asia have set up a system of international organizations and cooperation programs, strictly confined to the community (or Commonwealth) of socialist nations.

In the military field this cooperation began with a network of bilateral alliances and resulted in 1955 in establishing a Warsaw Treaty Organization which is a military alliance comparable to NATO. Economic cooperation of the socialist countries is directed by the Council for Mutual Economic Aid (COMECON). Established in 1949 to regulate and render technical assistance in trade relations. COMECON grew into an important center dealing with all forms of economic relations, with the ultimate purpose of intergrating the socialist countries into one system based upon a regional plan for the distribution of various economic responsibilities and functions. The Council for Mutual Economic Aid is in charge of planning, technical and scientific assistance, and research to bring about this ultimate goal.

Started as a fairly modest organization, COMECON consists now of a great number of technical organizations, including permament commissions for indidividual industrial branches or specific fields of economic activities, located in the capitals of the COMECON countries, and an international bank established in 1962 to finance various phases of economic cooperation. The principle of integration is that the industrial system of the Soviet Union and its vast natural resources, including all types of fuels, raw materials, rare metals, and its enormous market potentialities are to serve as a base for the economic systems of other socialist countries.

COMECON assists the economic activity of the member countries by unification of international trade regulations; by planning various phases of the integration program, stressing the development plans conceived in the perspective of common needs of the entire bloc; and assisting in the realization of the cooperative projects designed to serve the economy of a number of COMECON countries. The latter include various transport facilities (pipelines and power grids), railway communica- 
tions, development of air and sea fleets, developments of extractive industries, and market research to place commodity surpluses available in the member countries.

COMECON activities are supported by a number of technical organizations in charge of special fields of international cooperation between the socialist countries. These include railway and river transport organizations, conferences of government departments dealing with communications and custom formalities, the Joint Institute for Nuclear Research, the Danubian Commission, and various organizations for the protection of the maritime and fresh water fisheries.

Taken as a whole, the scope of economic and political cooperation of the Commonwealth of the Socialist Countries, centered upon the idea of their economic integration, is without precedent in international relations. Its purpose is to organize a vast area stretching from Central Europe to the Pacific Ocean washing the shores of Asia into a single economic system. In terms of historical experience it is comparable to the growth of the American economy. In terms of plans of social and economic integration it is comparable to the Common Market. Yet it is fair to mention that the simile is valid in a limited sense only. American economy filled the great void, and was the achievement of individual initiative. The Common Market programs bring about the economic integration of Europe by releasing economic initiative from the restrictions of national boundaries with as little interference of governmental authority as possible. Unification action is concerned with the equalization of social and opportunity conditions, and with prevention of discrimination by the governmental authorities of the participating countries. In addition, Common Market programs are only a return to the economic unity of Europe, which was already once a historical reality.

In contrast the program of the socialist integration envisions a totally novel experience. It relies primarily upon the cooperation of governments and of specialized governmental agencies. It is centrally planned and calls for detailed agreements between the governments concerned. It is therefore not surprising that in terms of governmental organization, it surpasses anything hitherto experienced in the history of human government. It is also not surprising that in terms of actual performance the results fall far short of achievements in the art of administrative buildup.

\section{IV}

\section{Cooperation in Universal International Organizations: Equality and Veto}

In summarizing the history of the East-West cooperation within the framework of the United Nations it would not be unfair to state that absence of accord in practical cases is due to differences in some basic concepts between the socialist and free economy countries. They have to do with the aims and goals of the international cooperation, the role of the United Nations in our times, and the meaning of some basic concepts of international law. The end result of those differences is that the Soviet Union and its allies among the socialist countries are unable to 
agree to common approach with the Western powers in situations in which ideological differences are involved. They are opposed to efforts which are aimed at the stabilization of social and economic conditions. They see the purpose of economic assistance not in the strengthening of the free institutions, but in the development of planned economy systems. In the Soviet view, economic cooperation and movement of capital should not be the business of individual initiative, but the instrument of national control of economic resources. National independence has a meaning in the socialist political dictionary that will not be found in more traditional systems of political thinking.

These differences, which frequently give occasion to Soviet use of veto power, are the ultimate reason why a vast majority of U.N. members seek new ways and techniques to fulfill the basic aims and purposes of the United Nations Organization, which again is a source of irritation and conflict between the socialist and free economy countries. The growing membership of the United Nations is a source of pressure upon its institutions to effect change and to increase the influence of the smaller countries. The growing needs of the modern world and the presence of great forces of destruction call for a reform of the United Nations Organization to make it more effective, and a better tool in meeting some of the basic problems of our times.

It would not be true to state that the Soviet Union is insensitive to the trends in the public opinion of the world, and if it sees no possibility to make concession to that point of view it is so because of important reasons fundamental to its position.

A good deal of Soviet attitude to international cooperation with the states of different social order is due to the feeling of isolation, of the Soviet Union specifically, and of the socialist states as a whole in a world in which the free economy countries still vastly outnumber the members of the Soviet bloc.

This sense of isolation was born at the moment when the Soviet régime realized that the October revolution would not be followed by communist revolutions in other countries of Europe. As a result, any plan of political or economic cooperation with the outside world had to resolve the question of how to neutralize the capitalist majority in any situation in which it would have a bearing on conditions and circumstances of cooperation. Lenin's notes made on Chicherin's memorandum in connection with the departure of the Russian delegation to the Conference of Genoa (April-May rg22), which came with full documentation ready to justify a total rejection of all plans for reconciliation, were almost exclusively concerned with this problem. In order that the Russian delegation might have some chance of success at the conference table which would draft plans of cooperation, Lenin insisted that the Conference should include participation on equal footing of colonial and dependent nations. The Conference should also admit workers' organizations, and accept a general principle of nonintervention of international organizations in the internal affairs of the member countries. Similarly, Lenin insisted on full equality and numerical parity of representation in all procedures 
concerned with the settlement of disputes between the socialist and capitalist nations. As regards international arbitration, Lenin thought that only such court of international arbitration which would consist of an "even number of members, delegated by both parties, so that half of the members would be imperialists and half communists,"

The same concern with numbers manifested itself when it became obvious towards the end of the last World War that the Soviet Union would not be able to retain the position of isolation and would have to participate in the activities of the United Nations Organization. The formula for political action in the new world was the unanimity and concerted action of all big powers so conceived that the opposition of one would block all effective action. In his report to the Supreme Soviet on November 6, 1944, Stalin warned that the actions of the future international organization in safeguarding peace shall only be effective if the great powers "shall act in the spirit of unanimity and agreement. They will not be effective if this basic premise is violated."

The immediate post-war experiences in the conference room, where Soviet leaders were forced to sit and debate various political and legal problems, have strengthened even further their dislike of voting procedures. Diplomacy and negotiations had little to do with deciding questions by putting them to vote. Molotov, who was the chief Soviet delegate to the Paris Peace Conference of I946, on several occasions complained bitterly against the voting technique. During the closing session of the Peace Conference, he denounced the "voting machine" which forced him to abandon many of his "just" claims. He indicated that the Soviet delegation favored the unanimity principle, which makes it impossible to settle international questions at the expense of the weaker party. He spoke darkly of the dangers associated with the technique of decision by the majority vote:

Veto prevents an agreement of three or four of the big powers to conspire against one of them. Veto promoted cooperation between the major powers, which is in the interest of all United Nations and of the entire world.10

He was convinced that the unanimity principle is superior to the majority vote.

The principle of veto requires that great powers must pay attention to their common interests ... preventing the emergence of groupings or of blocs of states directed against other states, and making it difficult to intrigue with aggressors behind the backs and contrary to the interests of the peace loving nations. ${ }^{11}$

As the number of the socialist countries grew into a system of socialist states, the principle of veto became a basic condition to the cooperation between two state

${ }^{8}$ Zajavlenie sovetskoi delegatsii na pervom plenarnom zasedanii Genuezkoi konferentsii (Declaration of the Soviet Delegation on the First Plenary Meeting of the Genoa Conference), in 5 Dokumenrs vNESHNeI POLITIKI SSSR (DocUments on Foreign Policy of THE USSR) I9I-94 (I961).

${ }^{\circ}$ Pravda, Nov. 7, I944.

${ }_{10}$ Molotov, Rechy na Paryzsror konferentsil (Speeches at the Paris Conference) I16 (1946):

${ }^{11}$ Id. at II8. 
systems. The Soviet right to veto any political decision made by the Security Council guarantees the equality and sovereign rights of the socialist states. It became thus a principle of peaceful co-existence within the United Nations Organization. Chairman Khrushchev stressed the wisdom of the Founding Fathers of the U.N. who "accorded equal rights to each of the great powers, members of the Security Council, including the Soviet Union, although at that time socialist countries were in an absolute minority. At that time only the Soviet Union and the Mongolian People's Republic were socialist states. Nevertheless, the Soviet Union was given the same rights as all other members of the Security Council." In his opinion the socialist states were given the same rights to influence the course of public affairs in the world as all other capitalist states. ${ }^{12}$

Furthermore, the right of veto was a political necessity. As a Soviet jurist wrote:

The Soviet Union could not but take into account that in the course of the pre-war years the policy of Western powers towards the Soviet Union was reactionary and high-handed. It had to remember that anti-Soviet policy was the backbone of the foreign policy of the Western Powers. ... ${ }^{13}$

In support of the Soviet government position Soviet jurists came out with a number of legal doctrines, which have promoted the principle of unanimity of great powers in the Security Council, and of the institution of veto to the central principle of the decision mechanism in the United Nations.

The highly authoritative 1957 edition of the Soviet treatise on international law prepared with the participation of the leading Soviet jurists expressed the view that:

The negative vote of a permanent member (of the Security Council) means that the decision was rejected. If the permament member decided to refrain from voting, indicating that this should not be considered as a negative vote ... the Council has the right to adopt the decision. Absence of a permament member of the Council, announced before hand, makes it impossible for the Council to adopt any decision, except in matters of procedure, as in this case there is no agreement between all the members of the Security Council.

It is necesary to state in this connection, the absolute illegality of decisions made by

${ }^{19}$ N. S. KHRUShchev, Za MIR, za razoruzhenie, za svobodu Narodov (For Peace, Disarmament and Freedom of PeOples), 288 . Cf. also Bobrov, Printsip ravnopravia duukh system v souremennom mezhdunarodnom prave (The Principle of Equality of the Two Systems in Contemporary International Law), [Ig60] Sovetskoe Gosudarstvo I Pravo, No. II; N. A. Ushakov, Printsip jedinoglassia velikikh derzhinv v Organizatsil Objedinonnikh Natsi (The Principle of Unanimitx of the Great Powers in THE UNITED NATIONS) 39-40 (1956).

${ }^{13}$ Ushaxov, op. cit. supra note I2, at 39 .

"The Security Council differs from all other organs of the United Nations also in this respect, that it alone has the authority to make decisions, which are obligatory for all members of the Organization, while the Charter contains no obligation to fulfil the recommendations passed by the General Assembly, or other main organs of the United Nations. Only the Security Council has the power to adopt measures, to uphold international peace and security, while the General Assembly, which was authorized to examine "all problems connected with maintaining international peace and security" must all such problems, requiring such a measure, submit to the Security Council prior or after its examination." Id. at 51 . 
the Security Council in $195^{\circ}$ in the matter of Korea in the absence of repersentatives from the Soviet Union and the People's Republic of China.. ${ }^{14}$

Soviet jurists also found that the veto principle is strengthened by the fact that in contrast with the League of Nations, which had set up the principle of equality of the Council and the League Assembly, the United Nations Charter made a distinction between the respective positions of the General Assembly and of the Security Council assigning, them different responsibilities. In this setup, the position of the General Assembly is definitely inferior:

-.. permanent members of the Security Council bear singular responsibility for the preservation and strengthening the world peace and security ... which is expressed ... in this, that according to the Charter, the Council is this organ, which is exclusively competent to institute international sanctions to support international peace and security. The United Nations Organization differs in this particular point from the League of Nations, that the Security Council is the only UNO body, which can institute measures of this type. ${ }^{15}$

As the unanimity principle in its United Nations version is the only platform on which socialist and free economy countries can establish working relations, it assures the universal character of the U.N. As it is absolutely necessary to preserve this universal character, the unanimity principle is the cornerstone of the present public order of the world. It must be adhered to, come what may. As Judge Winiarski from Poland, one of the important representatives of this trend of thought in the International Court of Justice, stated in his separate opinion in the case of Certain Expenses of the United Nations:

... it has been asserted that the purposes and in particular the maintenance of international peace and security may provide legal justification for certain decisions, even if these are not in conformity with the Charter, and that in any event a consideration of the purposes must furnish guidance as to the interpretation of the Charter. In the case before the Court, however, this argument certainly has not the importance, which there is temptation to attribute to it; ... The Charter has set forth the purposes of the United Nations in very wide, and for that reason too indefinite terms. . . . It does not follow, far from it, that the Organization is entitled to seek to achieve those purposes by no matter what means. The fact that an organ of the United Nations is seeking to achieve one of those purposes does not suffice to render its action lawful. . . .

The intention of those who drafted it, was clearly to abandon the possibility of useful action, rather than sacrifice the balance of carefully established fields of competence. . . . It may be that the United Nations is sometimes not in a position to undertake action which would be useful for the maintenance of international peace and security, or for another of the purposes indicated in Article I of the Charter, but that is the way the Organization was conceived and brought into being. ${ }^{16}$

Professor Krylov developed this line of thought somewhat further:

\footnotetext{
14 Mezhdunarodnoe Pravo (Internationat Law) 330 (I957).

${ }^{15}$ Ushakov, op. cit. supra note 12, at 65; see also, F. I. Kozhevnikov (Ed.), Mezhdunarodnoz Pravo (INTERNATIONAL LAw) 321, 325 (1957).

${ }^{16}$ [I962] I.C.J. REP. 230.
} 
The sovereign equality of the UN members finds expression in the fact, that each country has only one voice. The fact that some decisions of the United Nations organs are made by the majority vote does not affect that sovereignty, in particular as the U.N. General Assembly makes only recommendations, which do not create obligations upon individual states unless expressly accepted by such states. Furthermore, General Assembly decisions imposed upon the dissenting minority by the mechanical majority vote, if the minority's interests are in accordance with the aims and principles of the Charter of the United Nations, must be regarded as deprived of legal force. The minority has the right to reject those decisions. ${ }^{17}$

\section{SUMMARY}

To summarize, Soviet attitude to the role of international organizations in our time seems to reflect a set of conflicting principles. The Soviet government on the whole has no reservation against participation in the work of technical and specialized organizations, provided they do not have a general purpose of economic assistance. Soviet leaders are fully aware that some of the technical problems of our civilization call for international cooperation.

The Soviet government sees the importance of collective effort and the full identification of national interests with those of the larger group of nations within the framework of the socialist system of states.

International cooperation within the U.N. framework is conditioned by the practical, case-to-case coordination of the interests of the socialist states with those of states belonging to the different social and economic order. Soviet participation in the United Nations represents a limited engagement and partial identification of its national interests with those of the world at large. In this connection, the concept of national sovereignty and of the legal equality of all members of the international community becomes rather a concept of the legal equality and of political independence of the two state systems, which must not, either directly or indirectly by means of an international organization, interfere in each other's domestic affairs.

\footnotetext{
${ }^{17}$ Krylov, Istoria sozdania Organizatsil Objedinonnikh Natsil (The History of the Creation of the United Nations Organization) 258 (r952). Cf. Morozov, Organizatsia Objedinonnikh Natsil (United Nations Organizaton) I68 (I962).
} 